\title{
ANALISIS SERVQUAL BERDASARKAN PERSEPSI DAN EKSPEKTASI SISWA TERHADAP LAYANAN PENDIDIKAN DI SEKOLAH MENENGAH KEJURUAN
}

\author{
Hardiansyah \\ Program Studi Administrasi Pendidikan, FIPP UNDIKMA \\ Email: hardiansyah@ikipmataram.ac.id
}

\begin{abstract}
Abstrak: Layanan pendidikan merupakan jasa yang diberikan oleh pihak penyedia jasa atau sekolah kepada siswa. Kualitas layanan pendidikan dapat diketahui dengan cara membandingkan persepsi dan ekpektasi siswa terhadap layanan pendidikan yang benar-benar mereka peroleh selama proses pendidikan yang ditempuh di sekolah. Pemasalahan penelitian ini adalah bagaimanakah kualitas layanan pendidikan di SMK Darul Qur'an Bengkel Lombok Barat. Tujuan penelitian ini adalah untuk mengetahui kualitas layanan pendidikan di SMK Darul Qur'an Bengkel Lombok Barat. Populasi dalam penelitian adalah seluruh siswa SMK Darul Qur'an Bengkel Lombok Barat sebanyak 64 siswa dan sampel dalam penelitian adalah seluruh populasi yang berjumlah 64 siswa. Metode pengumpulan data yang digunakan adalah metode kuesioner. Metode analisis data yang digunakan adalah item-by-item gap analysis dan dimention-by-dimention gap analysis. Hasil deskripsi variabel penelitian menunjukkan variabel ekspektasi siswa dalam kategori tinggi dan variabel persepsi siswa dalam kategori memuaskan. Hasil penelitian di peroleh informasi bahwa dari lima dimensi kualitas layanan (bukti fisik, kehandalan, daya tanggap, jaminan dan empati) semuanya memiliki nilai negatif yaitu nilai persepsi lebih rendah dari nilai ekspektasinya. Artinya layanan pendidikan yang harapkan siswa belum dipenuhi oleh sekolah. Berdasarkan hasil penelitian disimpulkan bahwa secara umum kualitas layanan pendidikan di SMK Darul Qur'an Bengkel Lombok Barat masih rendah. SMK Darul Qur'an Bengkel Lombok Barat hendaknya berupaya meningkatkan kualitas layanan pendidikan dengan melibatkan siswa maupun orang tua siswa sebagai pelanggan. Adapun peningkatan kualitas yang perlu diprioritaskan yaitu pada atribut penjagaan kebersihan ruang kelas dan lingkungan sekolah, penyediaan buku perpustakaan, dan penguasaan metode penilaian hasil belajar oleh guru.
\end{abstract}

Kata Kunci: Kualitas Layanan, Persepsi dan Ekspektasi siswa, Layanan Pendidikan

\section{LATAR BELAKANG}

Pendidikan memiliki peranan penting dalam proses pembangunan suatu bangsa karena sasaran pendidikan adalah peningkatan kualitas sumber daya manusia. Tujuan dari peningkatan kualitas sumber daya manusia ini yaitu untuk mencetak generasi muda bangsa Indonesia yang mampu menjaga kelanjutan pembangunan nasional di segala bidang menuju tercapainya masyarakat yang adil dan sejahtera di masa mendatang. Untuk mewujudkan cita-cita tersebut Indonesia mengembangkan Sistem Penjaminan Mutu dan Peningkatan Mutu Pendidikan sebagai langkah untuk menyelenggarakan pelayanan pendidikan yang berkualitas.

Sistem jaminan mutu (Quality assurance) ialah sistem tentang pencapaian suatu tingkat kualitas tertentu berdasarkan prosedur-prosedur. Tujuannya ialah mencapai suatu tingkat kualitas tertentu yang telah ditetapkan sebelumnya. Adapun quality assurance yang diterapkan di sekolah menengah yaitu kegiatan penjaminan mutu yang mencakup aspek pendidikan, seperti mutu siswa, kurikulum, proses belajarmengajar, penilaian hasil belajar, pengembangan bahan media ajar dan sebagainya (Basuki, 2004).

Sekolah merupakan salah usaha yang menawarkan jasa pendidikan salah satunya yaitu Sekolah Menengah Kejuruan (SMK). Sekolah menengah kejuruan merupakan sekolah-sekolah yang program pendidikannya mengarah kepada pemberian bekal kecakapan atau keterampilan khusus agar lulusan siap dalam memasuki dunia kerja. Departemen Pendidikan Nasional saat ini benar-benar serius untuk menempatkan Sekolah Menengah Kejuruan (SMK) pada posisi $70 \%$ berbanding 30\% untuk SMA. Arah ke sana bukan hanya legal formal, tapi bisa dilihat dari usaha memasarkan SMK agar diminati lulusan SLTP dilakukan secara gencar di berbagai media. Program dan kegiatan pembangunan pendidikan kejuruan diorientasikan pada tujuan strategis 
pembangunan pendidikan menengah kejuruan yang mengacu pada Rencana Strategis Kementerian Pendidikan dan Kebudayaan, yaitu "tersedianya dan terjangkaunya layanan pendidikan menengah kejuruan yang bermutu, relevan, dan berkesetaraan di semua provinsi, kabupaten, dan kota". Pembangunan bidang pendidikan diarahkan demi tercapainya pertumbuhan ekonomi yang didukung keselarasan antara ketersediaan tenaga terdidik dengan kemampuan: menciptakan lapangan kerja atau kewirausahaan, dan menjawab tantangan kebutuhan tenaga kerja”. Dari uraian tersebut dapat di ketahui bahwa salah satu prioritas pemerintah yaitu untuk meningkatkan akses pendidikan yang berkualitas.

SMK Darul Qur'an merupakan salah salah satu penyelanggara pendidikan kejuruaan di Kabupaten Lombok Barat. SMK Darul Qur'an ini di bawah naungan Yayasan Darul Qur'an Bengkel. 2007 SMK Darul Qur'an memiliki jurusan yaitu Jurusan Teknik Komputer Jaringan. Dengan berjalannya waktu, seiring banyaknya SMK Negeri yang terbentuk, sejak tahun 2007 hingga 2013 SMK Darul Qur'an ternyata tidak bisa meningkatkan animo pendaftar secara signifikan. Sehingga di tahun 2014 dibentuk satu jurusan baru yaitu Teknik Bisnis Sepeda Motor. Sehingga sampai saat ini hanya 2 jurusan yang ada di SMK Darul Qur'an. Berdasarkan wawancara yang dilakukan kepada kepala sekolah dan guru diperoleh informasi bahwa rendahnya peminatan dari masyarakat dikarenakan pembiayaan pendidikan yang dimiliki oleh yayasan yang terbatas sehingga upaya untuk peningkatan mutu pendidikan menjadi tidak maksimal. Selain itu adanya sekolah lain yang lebih baik, sehingga SMK Darul Qur'an ini menjadi pilihan terakhir setelah tidak diterima pendaftarannya di sekolah lain. Dengan demikian input yang diperoleh oleh sekolah merupakan siswa dengan tingkat intelegensi yang rendah yang kemudian mengakibatkan pengembangan potensi siswa tidak dapat maksimal, sehingga timbul kesan dimasyarakat bahwa lulusan
SMK Darul Qur'an ini memiliki kualitas rendah. Di sisi lain, setelah peneliti mewancarai beberapa siswa diperoleh informasi bahwa menurut mereka kualitas layanan yang diberikan oleh pihak sekolah belum baik, terutama yang berkaitan dengan sarana prasarana.

Untuk itu perlu adanya upaya peningkatan mutu pendidikan di SMK Darul Qur'an secara tepat dan efektif. Dengan demikian maka perlu di lakukan penelitian lebih mendalam pada bagian manakah yang perlu ditingkatkan. Untuk mengetahui tingkat kualitas layanan pendidikan di SMK Darul Qur'an, pada penelitian ini akan dikaji tentang bagaimana kualitas layanan pendidikan SMK Darul Qur'an dilihat dari persepsi siswa dan ekspektasi siswa terhadap layanan pendidikan.

\section{TINJAUAN PUSTAKA}

\section{Kualitas Layanan (Service Quality)}

\section{Pengertian Kualitas Layanan}

Service atau layanan adalah bentuk produk yang terdiri dari aktivitas, manfaat atau kepuasan yang ditawarkan untuk dijual dan pada dasarnya tidak berwujud dan tidak menghasilkan kepemilikan akan sesuatu (Kotler, 2008:66).

Menurut Tjiptono (2007:59) yang dimaksud dengan kualitas pelayanan adalah tingkat keunggulan untuk memenuhi keinginan pelanggan. Keunggulan suatu produk jasa tergantung pada keunikan serta kualitas yang diberikan oleh penyedia jasa, apakah sesuai atau belum dengan ekspektasi pelanggan.

Kualitas pelayanan (service quality) dapat diketahui dengan cara membandingkan persepsi para konsumen atas pelayanan yang nyata-nyata mereka terima atau peroleh dengan pelayanan yang sesungguhnya mereka harapkan/inginkan terhadap atributatribut pelayanan suatu perusahaan. Gronroos (1992) mengemukakan bahwa terdapat empat faktor yang mempengaruhi kualitas pelayanan, yaitu : 1) Menjaga dan memperhatikan, bahwa pelanggan akan merasakan karyawan dan sistem operasional 
yang ada dapat menyelesaikan problem mereka; 2) Spontanitas, dimana karyawan menunjukkan keinginan untuk menyelesaikan masalah pelanggan; 3) Penyelesaian masalah, karyawan yang berhubungan langsung dengan pelanggan harus memiliki kemampuan untuk menjalankan tugas berdasarkan standar yang ada, termasuk pelatihan yang diberikan untuk dapat memberikan pelayanan yang lebih baik; 4) Perbaikan, apabila terjadi hal-hal yang tidak diinginkan harus mempunyai personel yang dapat menyiapkan usah-usaha khusus untuk mengatasi kondisi tersebut.

\section{Kualitas Layanan di Bidang Pendidikan}

Sekolah merupakan organisasi nirlaba yang menyediakan jasa pendidikan. Bentuk layanan dalam bidang pendidikan yaitu berupa jasa. Menuru Tjiptono (2008:15) jasa merupakan aktivitas, manfaat, atau kepuasan yang ditawarkan untuk dijual. Berdasarkan tujuannya organisasi, jasa/layanan dapat diklasifikasikan menjadi dua, yaitu: commercial service atau profit service (misalnya jasa penerbangan, persewaan mobil, biro iklan, dan hotel) dan non-profit service (seperti sekolah, yayasan dana bantuan, panti asuhan, panti wreda, instansi pemerintah, perpustakaan umum, dan museum).

Pemerintah dalam menjamin kualitas layanan dibidang pendidikan diwujudkan dengan Standar Nasional Pendidikan (NSP). Dalam kerangka sistem, komponen input sistem pemenuhan SNP adalah Standar Kompetensi Pendidik dan Tenaga Kependidikan (PTK), Standar Pengelolaan, Standar Sarana dan Prasarana (Sarpras), dan Standar Pembiayaan. Bagian yang termasuk pada komponen proses adalah Standar Isi, Standar Proses, dan Standar Evaluasi, sedangkan bagian yang termasuk pada komponen output adalah Standar Kompetensi Lulusan (SKL).

\section{Persepsi}

Persepsi adalah proses yang mana seseorang mengorganisasikan dan mengintreprestasikan kesan-kesan sensorinya dalam usaha memberikan sesuatu makna tertentu kepada lingkunganya (Siagian, 2004:100). Menurut Toha (2003: 141) persepsi adalah proses kognitif yang dialami oleh setiap manusia dalam memahami lingkungannya baik lewat penglihatan, pendengaran, penghayatan, perasaan maupun penciuman. Sedangkan menurut Walgito (2003:89) Persepsi adalah suatu proses yang didahului oleh proses penginderaan, yaitu merupakan proses diterimanya stimulus oleh individu melalui alat indera atau juga disebut proses sensoris.

Rakhmat (2003:51) mendefinikan persepsi sebagai pengalaman tentang obyek, peristiwa, atau hubungan-hubungan yang diperoleh dengan menyimpulkan dan menafsirkan pesan. Persepsi merupakan suatu proses yang didahului oleh proses indera, yaitu merupakan proses diterimanya stimulus oleh individu melalui alat indera. Stimulus yang dikenai alat indera tersebut kemudian diorganisasikan, di interpretasikan sehingga individu menyadari tentang apa yang diinderanya itu. Dengan demikian dapat dikemukakan bahwa persepsi itu merupakan pengorganisasian, penginterpretasian terhadap stimulus yang diinderanya sehingga merupakan sesuatu yang berarti, dan merupakan respon yang integrated dalam individu. Dengan persepsi individu akan menyadari tentang keadaan sekitarnya juga keadaan dirinya sendiri.

Dari uraian di atas maka dapat disimpulkan persepsi adalah proses dimana individu-individu mengorganisasikan dan mengintrepetasikan kesan-kesan melalui indera penglihatan, pendengaran, penghayatan, perasaan maupun penciuman dalam usaha memberikan sesuatu makna tertentu kepada lingkunganya.

\section{Faktor-Faktor yang Memengaruhi Persepsi}

Sarlito (2002:49) menjelaskan bahwa persepsi dipengaruhi oleh beberapa hal, sebagai berikut:

1) Perhatian: Seluruh rangsangan yang ada disekitar kita, tidak dapat kita tangkap sekaligus, tetapi harus difokuskan pada 
satu atau dua obyek saja. Perbedaan fokus antara satu orang dengan orang yang lain menyebabkan terjadinya perbedaan persepsi.

2) Set: harapan seseorang akan rangsang yang akan timbul. Perbedaan set juga akan menyebabkan perbedaan persepsi.

3) Kebutuhan: Kebutuhan sesaat maupun menetap dalam individu akan mempengaruhi persepsi orang tersebut. Kebutuhan yang berbeda akan menyebabkan persepsi yang berbeda pula bagi tiap-tiap individu.

4) Sistem nilai: Sistem nilai yang berlaku di dalam masyarakat juga berpengaruh terhadap persepsi seseorang.

\section{Persepsi Terhadap Layanan Pendidikan}

Kualitas layanan harus dimulai dari kebutuhan pelanggan dan berakhir dengan kepuasan pelanggan serta persepsi positif terhadap kualitas layanan. Sebagai pihak yang membeli dan mengkonsumsi produk atau jasa, pelanggan (dan bukan produsen atau penyedia layanan jasa) tingkat kualitas layanan sebuah perusahaan (Tjiptono, 2008:157). Tantangannya, penilaian konsumen terhadap kinerja layanan yang diterimanya bersifat subjektif, karena tergantung persepsi masing-masing individu. Hidangan yang sama di sebuah restoran bisa jadi dinilai berbeda oleh orang berbeda; ada yang bilang kurang manis, kurang pedas, kurang asin, pas, terlalu manis, terlalu pedas, terlalu banyak santannya, dan lain-lain. Ini semua akan mempengaruhi penilaian akhir terhadap kualitas layanan restoran yang bersangkutan.

Lebih lanjut, persoalan lebih kompleks dihadapi para pemasar jasa yang salah satu karakteristiknya adalah variability, di mana kinerjanya acapkali tidak konsisten. Hal ini menyebabkan pelanggan menggunakan isyarat/petunjuk intriksik dan isyarat ekstrinsik sebagai acuan/pedoman dalam mengevaluasi kualitas layanan. Isyarat intrinsik berkaitan dengan output dan penyampaian sebuah jasa. Pelanggan akan mengandalkan isyarat semacam ini apabila berada di tempat pembelian atau jika isyarat intrinsik bersangkutan merupakan search quality (atribut kualitas yang bisa di inspeksi atau dievaluasi sebelum pembelian dilakukan, contohnya harga) dan memiliki prediktif tinggi.

Sedangkan yang dimaksud dengan isyarat ekstrinsik adalah unsur-unsur yang merupakan pelengkap bagi sebuah jasa. Isyarat ini dipergunakan dalam mengevaluasi jasa jika proses menilai isyarat intrinsik membutuhkan banyak waktu dan usaha, dan apabila isyarat ekstrinsik yang bersangkutan merupakan experience quality (elemen kualitas yang hanya bisa dinilai setelah mengkonsumsi jasa, contoh kualitas bedah jantung). Isyarat ekstrinsik juga dipakai sebagai indikator kualitas layanan manakala tidak tersedia informasi isyarat intrinsik yang memadai. Sementara itu, partisipasi dan interaksi pelanggan dalam proses penyampaian jasa juga ikut menentukan kompleksitas evaluasi kualitas jasa. Konsekuensinya, jasa yang sama bisa dinilai secara berlainan oleh konsumen yang berbeda. Dari uraian tersebut maka dalam penelitian ini menggunakan persepsi dengan isyarat ekstrinsik. Yaitu berupa pengalaman siswa terhadap layanan pendidikan di SMK Darul Qur'an Bengkel.

\section{Harapan/Ekspektasi}

Dalam konteks kualitas produk (barang dan jasa) dan kepuasan pelanggan, ada semacam konsensus bahwa ekspektasi pelanggan (customer expectation) memainkan peranan penting sebagai standar pembanding dalam mengevaluasi kualitas maupun kepuasan. Saat ini setidaknya berkembang 56 definisi ekspektasi pelanggan yang dijumpai dalam literatur kualitas layanan dan kepuasan pelanggan (santos \& boote dalam Tjiptono, 2008:159).

Tjiptono menegaskan bahwa dari delapan tipe ekspektasi diatas, hanya predicted (wiil) expectation yang paling banyak digunakan dalam literature kualitas layanan dan kepuasan konsumen. Harapan adalah apa saja yang konsumen pikirkan harus disediakan oleh penyedia jasa. 
Harapan bukan merupakan prediksi dari apa yang disediakan oleh penyedia jasa. Harapan konsumen terhadap layanan merupakan keinginan atau permintaan ideal konsumen terhadap layanan yang akan diberikan oleh penyedia layanan. Harapan konsumen harus menjadi acuan bagi penyedia layanan untuk mendesain, menghasilkan dan menyampaikan layanan kepada konsumen.

\section{METODE PENELITIAN}

Jenis Penelitian

Penelitian ini merupakan jenis penelitian deskriptif dengan menggunakan pendekatan kuantitatif. Penelitian deskriptif merupakan suatu penelitian yang berfungsi untuk mendeskripsikan atau memberi gambaran terhadap obyek yang diteliti untuk mengetahui nilai variabel, baik satu variabel atau lebih melalui data sampel atau populasi sebagaimana adanya.

\section{Jenis Data dan Teknik Pengumpulannya}

Metode pengumpulan data dilakukan dalam penelitian ini yaitu angket dan wawancara tidak terstruktur. Instrumen penelitian menggunakan angket (kuesioner) yang dikembangkan berdasarkan model SERVQUAL. Instrumen disampaikan kepada responden, yaitu siswa SMK Darul Qur'an Bengkel. Instrumen yang digunakan dalam penelitian ini menggunakan skala Likert dengan lima kategori yaitu skor 5 (sangat setuju), skor 4 (setuju), skor 3 (kurang setuju), skor 2 (tidak setuju), skor 1 (sangat tidak setuju) atas pelayanan pendidikan selama siswa menempuh pendidikan di satuan pendidikan.

Dalam penelitian ini akan di ukur layanan pendidikan berdasarkan standar nasional pendidikan yang disesuaikan dengan kebutuhan penilaian kualitas layanan pendidikan. Adapun penilaian kualitas layanan pendidikan pada SMK Darul Qur'an menggunakan penilaian yaitu: layanan sarana prasarana, layanan oleh tenaga pendidik atau guru, layanan oleh tenaga kependidikan atau karyawan, kurikulum yang dikembangkan, dan layanan bimbingan konseling.

Model penilaian kualiatas layanan pendidikan dalam penelitan ini akan mengacu pada model analisis SERVQUAL. Model ini didasarkan pada asumsi bahwa konsumen membandingkan kinerja layanan pada atribut-atribut relevan dengan standar ideal/sempurna untuk masing-masing atribut layanan. Bila kinerja sesuai atau melebihi standar, maka persepsi terhadap kualitas layanan keseluruhan akan positif dan sebaliknya. Dengan kata lain, model ini menganalisis gap antara dua variabel pokok, yakni layanan yang diharapkan (expected service) dan persepsi pelanggan terhadap layanan yang diterima (perceived service).

Pengukuran kualitas layanan pendidikan dalam penelitian ini didasarkan pada skala multi-item yang dirancang untuk mengukur ekspektasi dan persepsi siswa sebagai pelanggan, serta gap di antara keduanya pada lima dimensi utama kualitas layanan (bukti fisik, reliabilitas, daya tanggap, jaminan, dan empati). Kelima dimensi utama itu dijabarkan dalam masing-masing 20 atribut rinci untuk variabel ekspektasi dan variabel persepsi, yang disusun dalam pernyataanpernyataan berdasarkan skala Likert, dari 1 (sangat tidak setuju) sampai 5 (sangat setuju). Evaluasi kualitas layanan menggunakan model SERVQUAL mencakup perhitungan perbedaan antara nilai yang diberikan para pelanggan untuk setiap pasang pernyataan berkaitan dengan ekspektasi dan persepsi.

\section{Teknik Analisis Data}

Metode analisis data merupakan suatu metode yang digunakan untuk mengolah hasil penelitian guna memperoleh suatu kesimpulan. Dalam penelitian ini, metode analisis data yang digunakan yaitu:

1. Analisis item-by-item gap analysis. Caranya adalah menghitung selisih skor rata-rata persepsi dan skor rata-rata ekspektasi untuk masing-masing item. Dengan perhitungan ini maka akan diketahui kualitas layanan masing-msing item. 
2. Analisis dimention-by-dimention gap analysis. Caranya adalah rata-rata skor tiap dimensi (bukti fisik, reabilitas, daya tanggap, jaminan dan empati) persepsi dan ekspektasi harus dihitung. Kemudian nilai dari persepsi dikurangkan dengan nilai ekspektasi pada masingmasing dimensi. Hasil dari analisis ini akan dapat diketahui gap dari masingmasing dimensi untuk kemudian perbaikan bisa difokuskan pada dimensi yang memiliki nilai negatif (Tjiptono, 2008:221).

Evaluasi kualitas layanan menggunakan model SERVQUAL mencakup perhitungan perbedaan antara nilai yang diberikan siswa untuk setiap pasang pernyataan berkaitan dengan ekspektasi dan persepsi. Skor SERVQUAL untuk setiap pasang pernyataan, bagi masing-masing pelanggan dapat dihitung berdasarkan rumus berikut:

$$
\mathbf{Q}=\mathbf{P}-\mathbf{E}
$$

Dimana:

$\mathrm{Q}=$ Quality/Kualitas Pelayanan Pelanggan

$\mathrm{E}=$ Expectation/Harapan Pelanggan atas Kualitas Pelayanan

$\mathrm{P}=$ Perceived/Pelayanan yang sesungguhnya diterima

Berdasarkan rumus di atas, ketentuan penarikan kesimpulan atas kualitas layanan pendidikan yaitu sebagai berikut:

1. Jika Q > 0 maka ES > PS; siswa kurang puas atas pelayanan yang diterima;

2. Jika $\mathrm{Q}=0$ maka $\mathrm{ES}=\mathrm{PS}$; siswa puas atas pelayanan yang diterima;

3. Jika $\mathrm{Q}<0$ maka $\mathrm{EC}<\mathrm{PS}$; siswa sangat puas atas pelayanan yang diterima atau mengalami kondisi ideal.

Tabel perhitungan sebagai berikut:

\begin{tabular}{|c|c|c|c|}
\hline Responden & Excepted Service & Perceived Service & PS - ES \\
\hline R 1 & Mean 1 & Mean 1 & ps - es \\
\hline R 2 & Mean 2 & Mean 2 & ps - es \\
\hline$\ldots$ & $\ldots$ & $\ldots$ & $\ldots$ \\
\hline R N & Mean N & Mean N & psn - esn \\
\hline
\end{tabular}

Dimana :

ES $\quad=$ Skor Pelayanan yang diharapkan (ES)

$P S \quad=$ Rata-rata Skor Pelayanan yang dirasakan (PS)

$P S-E S \quad=$ Kesenjangan antara harapan dengan yang dirasakan $(\mathrm{Q})$

Interpretasi hasil perhitungan sebagai berikut:

\begin{tabular}{|c|c|}
\hline Hasil SERVQUAL & Kualitas Layanan \\
$\mathbf{Q} \mathbf{P}-$ & \\
\hline$>0$ & Ideal \\
\hline$=0$ & Baik \\
\hline$<0$ & Buruk \\
\hline
\end{tabular}

\section{HASIL PENELITIAN DAN \\ PEMBAHASAN \\ Hasil Penelitian \\ Uji Validitas}

Teknik yang digunakan untuk menguji validitas kuisoner yaitu dengan melakukan korelasi bivariate antara masing-masing skor item soal dengan total skor konstruk. Uji validitas diperoleh dengan menggunakan bantuan program SPSS for windows release 16.00. Untuk mengetahui apakah instrumen yang digunakan valid atau tidak, maka dilihat dari nilai sig dengan taraf signifikan 5\% atau 0,05 pada tabel corrrelations. Apabila nilai sig $\geq 0,05$ maka instrumen dikatakan valid, dan apabila nilai sig $\leq 0,05$ maka instrumen dikatakan tidak valid. Berikut disajikan uji validitas untuk masing-masing pernyataan per variabel.

1. Variabel ekspektasi siswa terhadap layanan pendidikan

Variabel ekspektasi siswa terhadap layanan pendidikan terdiri atas 25 butir 
soal pernyataan dapat digambarkan sebagai

berikut:

hasil uji validitas pada tabel 4.1

Tabel 4.1 Hasil Uji Validitas Variabel Ekspektasi Siswa Terhadap Layanan Pendidikan

\begin{tabular}{|c|c|c|c|}
\hline Korelasi antara & $\begin{array}{l}\text { Nilai Korelasi } \\
\text { (Pearson corellation) }\end{array}$ & $\begin{array}{l}\text { Probabilitas korelasi } \\
\text { [sig.(2-tailed)] }\end{array}$ & $\begin{array}{c}\text { Kriteria } \\
(\text { alpha 5\%) }\end{array}$ \\
\hline Item 1 dengan Total & 0,554 & 0,002 & Valid \\
\hline Item 2 dengan Total & 0,307 & 0,099 & Tidak Valid \\
\hline Item 3 dengan Total & 0,687 & 0,000 & Valid \\
\hline Item 4 dengan Total & 0,554 & 0,001 & Valid \\
\hline Item 5 dengan Total & 0,423 & 0,020 & Valid \\
\hline Item 6 dengan Total & 0,489 & 0,006 & Valid \\
\hline Item 7 dengan Total & 0,468 & 0,009 & Valid \\
\hline Item 8 dengan Total & 0,537 & 0,002 & Valid \\
\hline Item 9 dengan Total & 0,503 & 0,005 & Valid \\
\hline Item 10 dengan Total & 0,488 & 0,006 & Valid \\
\hline Item 11 dengan Total & 0,378 & 0,039 & Valid \\
\hline Item 12 dengan Total & 0,653 & 0,000 & Valid \\
\hline Item 13 dengan Total & $-0,026$ & 0,892 & Tidak Valid \\
\hline Item 14 dengan Total & 0,429 & 0,018 & Valid \\
\hline Item 15 dengan Total & 0,339 & 0,066 & Tidak Valid \\
\hline Item 16 dengan Total & 0,661 & 0,000 & Valid \\
\hline Item 17 dengan Total & 0,130 & 0,495 & Tidak Valid \\
\hline Item 18 dengan Total & 0,531 & 0,003 & Valid \\
\hline Item 19 dengan Total & 0,551 & 0,002 & Valid \\
\hline Item 20 dengan Total & 0,501 & 0,005 & Valid \\
\hline Item 21 dengan Total & 0,371 & 0,043 & Valid \\
\hline Item 22 dengan Total & 0,442 & 0,014 & Valid \\
\hline Item 23 dengan Total & 0,234 & 0,213 & Tidak Valid \\
\hline Item 24 dengan Total & 0,551 & 0,002 & Valid \\
\hline Item 25 dengan Total & 0,469 & 0,009 & Valid \\
\hline
\end{tabular}

Sumber: Data penelitian, September 2019

Dari tabel 4.1 Dari tabel di atas diketahui bahwa dari 25 butir pernyataan tentang ekspektasi siswa terhadap layanan pendidikan terdapat 5 butir soal yang tidak valid yaitu pada item pernyataan nomor $2,13,15,17$ dan 23 . Secara keseluruhan ada 20 item pernyataan yang valid dan digunakan sebagai alat pengambil data penelitian, 5 butir soal yang tidak valid dihilangkan karena indikator sudah terwakili dari item pernyataan yang valid.

2. Variabel persepsi siswa terhadap layanan pendidikan

Pada variabel persepsi siswa terhadap layanan pendidikan yang terdiri atas 25 butir soal pernyataan dapat digambarkan hasil uji validitas pada tabel 4.2 sebagai berikut:

Tabel 4.2 Hasil Uji Validitas Variabel Persepsi Siswa Terhadap Layanan Pendidikan

\begin{tabular}{|c|c|c|c|}
\hline Korelasi antara & $\begin{array}{c}\text { Nilai Korelasi } \\
\text { (Pearson corellation) }\end{array}$ & $\begin{array}{c}\text { Probabilitas korelasi } \\
\text { [sig.(2-tailed)] }\end{array}$ & $\begin{array}{c}\text { Kriteria } \\
\text { (alpha 5\%) }\end{array}$ \\
\hline Item 1 dengan Total & 0,554 & 0,002 & Valid \\
\hline Item 2 dengan Total & 0,307 & 0,099 & Tidak Valid \\
\hline
\end{tabular}




\begin{tabular}{|c|c|c|c|}
\hline Item 3 dengan Total & 0,687 & 0,000 & Valid \\
\hline Item 4 dengan Total & 0,554 & 0,001 & Valid \\
\hline Item 5 dengan Total & 0,423 & 0,020 & Valid \\
\hline Item 6 dengan Total & 0,489 & 0,006 & Valid \\
\hline Item 7 dengan Total & 0,468 & 0,009 & Valid \\
\hline Item 8 dengan Total & 0,537 & 0,002 & Valid \\
\hline Item 9 dengan Total & 0,503 & 0,005 & Valid \\
\hline Item 10 dengan Total & 0,488 & 0,006 & Valid \\
\hline Item 11 dengan Total & 0,378 & 0,039 & Valid \\
\hline Item 12 dengan Total & 0,653 & 0,000 & Valid \\
\hline Item 13 dengan Total & $-0,026$ & 0,892 & Tidak Valid \\
\hline Item 14 dengan Total & 0,429 & 0,018 & Valid \\
\hline Item 15 dengan Total & 0,339 & 0,066 & Tidak Valid \\
\hline Item 16 dengan Total & 0,661 & 0,000 & Valid \\
\hline Item 17 dengan Total & 0,130 & 0,495 & Tidak Valid \\
\hline Item 18 dengan Total & 0,531 & 0,003 & Valid \\
\hline Item 19 dengan Total & 0,551 & 0,002 & Valid \\
\hline Item 20 dengan Total & 0,501 & 0,005 & Valid \\
\hline Item 21 dengan Total & 0,371 & 0,043 & Valid \\
\hline Item 22 dengan Total & 0,442 & 0,014 & Valid \\
\hline Item 23 dengan Total & 0,234 & 0,213 & Tidak Valid \\
\hline Item 24 dengan Total & 0,551 & 0,002 & Valid \\
\hline Item 25 dengan Total & 0,469 & 0,009 & Valid \\
\hline
\end{tabular}

Sumber: Data penelitian, September 2019

Dari tabel 4.2 di atas diketahui bahwa dari 25 butir pernyataan tentang persepsi siswa terhadap layanan pendidikan terdapat 5 butir soal yang tidak valid yaitu pada item pernyataan nomor $2,13,15,17$ dan 23. Secara keseluruhan ada 20 item pernyataan yang valid dan digunakan sebagai alat pengambil data penelitian, 5 butir soal yang tidak valid dihilangkan karena indikator sudah terwakili dari item pernyataan yang valid.

\section{Uji Reliabilitas}

Uji reliabilitas digunakan untuk mengukur instrumen atau kuesioner dapat dipercaya atau tidak sebagai alat untuk pengambilan data penelitian. Instrumen yang baik tidak akan bersifat tendensius atau mengarahkan responden untuk memilih jawaban-jawaban tertentu. Reliabilitas menunjukkan tingkat kepercayaan dari suatu indikator yang digunakan dalam penelitian.

Uji reliabilitas dilakukan dengan bantuan program SPSS for windows release 16.00. Teknik yang digunakan yaitu dengan mengunakan uji statistik Cronbach Alpha. Suatu variabel dikatakan reliabel jika memberikan nilai Cronbach Alpha > 0,60. Berikut hasil uji reliabilitas dari masingmasing variabel sebagai berikut:

\section{Tabel 4.3 Hasil Uji Statistik Reliabilitas}

\begin{tabular}{|l|c|}
\hline \multicolumn{1}{|c|}{ Variabel } & Cronbach $^{\text {e's }}$ alpha \\
\hline Ekspektasi siswa terhadap layanan pendidikan & 0,803 \\
\hline Persepsi siswa terhadap layanan pendidikan & 0,836 \\
\hline
\end{tabular}

Berdasarkan tabel 4.3 diatas Alpha pada variabel ekspektasi siswa menunjukkan bahwa nilai Cronbach ${ }^{\text {ee }}$ terhadap layanan pendidikan dan variabel 
persepsi siswa terhadap layanan pendidikan lebih besar dari 0,60, sehingga kedua variabel tersebut dikatakan reliabel dan dapat digunakan sebagai alat pengambil data dalam penelitian.

\section{Analisis GAP 5 SERVQUAL}

\begin{tabular}{|c|c|c|c|c|c|c|c|}
\hline \multirow[t]{2}{*}{ No. } & \multicolumn{2}{|c|}{ Rata-Rata Per Item } & \multirow{2}{*}{$\begin{array}{l}\text { Persepsi- } \\
\text { Ekspektasi }\end{array}$} & \multirow{2}{*}{ Dimensi } & \multicolumn{2}{|c|}{$\begin{array}{c}\text { Rata-Rata Per Item } \\
\text { Dimensi }\end{array}$} & \multirow{2}{*}{$\begin{array}{c}\text { Skor } \\
\text { SERVQUAL }\end{array}$} \\
\hline & Persepsi & Ekspektasi & & & Persepsi & Ekspektasi & \\
\hline 1 & 3,6 & 4,5 & $-0,9$ & \multirow{5}{*}{$\begin{array}{l}\text { Bukti Fisik } \\
\text { (Item 1-5) }\end{array}$} & \multirow{5}{*}{3,6} & \multirow{5}{*}{4,2} & \multirow{5}{*}{$(0,6)$} \\
\hline 2 & 3,6 & 4,5 & $-0,6$ & & & & \\
\hline 3 & 3,5 & 4,1 & $-0,6$ & & & & \\
\hline 4 & 3,6 & 4 & $-0,4$ & & & & \\
\hline 5 & 3,6 & 4 & $-0,4$ & & & & \\
\hline 6 & 3,7 & 3,9 & $-0,2$ & \multirow{4}{*}{$\begin{array}{c}\text { Kehandalan } \\
\text { (Item 6, 13, } \\
14,15)\end{array}$} & \multirow{4}{*}{3,6} & \multirow{4}{*}{3,8} & \multirow{4}{*}{$(0,3)$} \\
\hline 7 & 3,4 & 3,9 & $-0,5$ & & & & \\
\hline 8 & 3,6 & 3,7 & $-0,1$ & & & & \\
\hline 9 & 3,5 & 3,8 & $-0,3$ & & & & \\
\hline 10 & 3,8 & 3,9 & $-0,1$ & \multirow{4}{*}{$\begin{array}{c}\text { Daya } \\
\text { Tanggap } \\
\text { (Item } 7,12, \\
18,20)\end{array}$} & \multirow{4}{*}{3,7} & \multirow{4}{*}{3,9} & \multirow{4}{*}{$(0,3)$} \\
\hline 11 & 3,7 & 4 & $-0,3$ & & & & \\
\hline 12 & 3,5 & 3,9 & $-0,4$ & & & & \\
\hline 13 & 3,6 & 3,9 & $-0,3$ & & & & \\
\hline 14 & 3,7 & 4 & $-0,3$ & \multirow{4}{*}{$\begin{array}{c}\text { Jaminan } \\
\text { (Item 8-11) }\end{array}$} & \multirow{4}{*}{3,6} & \multirow{4}{*}{3,9} & \multirow{4}{*}{$(0,3)$} \\
\hline 15 & 3,6 & 3,8 & $-0,2$ & & & & \\
\hline 16 & 3,6 & 3,9 & $-0,3$ & & & & \\
\hline 17 & 3,7 & 4 & $-0,5$ & & & & \\
\hline 18 & 2,7 & 3,8 & $-1,1$ & \multirow{3}{*}{$\begin{array}{c}\text { Empati } \\
\text { (Item 16, } \\
17,19 \text { ) }\end{array}$} & \multirow{3}{*}{3,4} & \multirow{3}{*}{3,9} & \multirow{3}{*}{$(0,5)$} \\
\hline 19 & 3,8 & 4 & $-0,2$ & & & & \\
\hline 20 & 3,7 & 3,9 & $-0,2$ & & & & \\
\hline
\end{tabular}

\section{Pembahasan}

Ada lima dimensi kualitas layanan yang dijadikan indikator penelitian ini yaitu dimensi bukti fisik, dimensi kehandalan, dimensi daya tanggap, dimensi jaminan dan dimensi empati. Dari lima indikator tersebut semuanya memiliki nilai negatif yaitu nilai persepsi lebih rendah dari nilai ekspektasinya. Sehingga secara umum kualitas layanan pendidikan di SMK Darul Qur'an Bengkel dapat diinterpretasikan buruk. Untuk itu perlu adanya upayaupaya perbaikan kualitas layanan oleh pihak sekolah. Pada dimensi bukti fisik dan dimensi empati, tingkat skor SERVQUALnya mencapai $-0,6$ dan -0,5. Dalam masing-masing dimensi tentunya memiliki item-item tentang persepsi dan ekspektasi siswa yang tentunya perlu untuk dibenahi dan diprioritaskan bagi kepala sekolah seperti pada atribut penjagaan kebersihan ruang kelas dan lingkungan sekolah, penyediaan buku perpustakaan, dan penguasaan metode penilaian hasil belajar oleh guru. Sehingga dalam pengembangannya, sekolah tidak dapat bergerak dengan sendirinya, tentu mengharapkan peran aktif sivitas yayasan, kepala sekolah, siswa, orang tua siswa, dan stakeholder baik dari tataran pemerintah maupun lembaga swasta sebagai pelanggan.

\section{KESIMPULAN}

Berdasarkan hasil penelitian dan pembahasan maka dapat ditarik kesimpulan antara lain:

1. Ada lima dimensi kualitas layanan yang dijadikan indikator penelitian ini yaitu dimensi bukti fisik, dimensi kehandalan, dimensi daya tanggap, dimensi jaminan dan dimensi empati. Dari lima indikator tersebut semuanya memiliki nilai negatif yaitu nilai persepsi lebih rendah dari nilai ekspektasinya.

2. Secara umum kualitas layanan pendidikan di SMK Darul Qur'an Bengkel masih terinterpretasi buruk. Untuk itu perlu adanya upaya-upaya 
perbaikan kualitas layanan oleh pihak sekolah.

\section{DAFTAR PUSTAKA}

Basuki dan Sumarno. 2004. Implementasi system jaminan mutu (Quality assurance) proses pembelajaran diperguruan tinggi. Jurnal Penelitian dan Evaluasi, Nomor 7, tahun VI. hal: 133-144

Hasnidawati. 2007. Mengoptimalkan paradigm pendidikan yang berkualitas dengan kolaborasi semua pihak. Jurnal guru. No. 1 vol. 4 Juli 2007 : 27-34

Kotler, Philip \& Armstrong, Garry, 2008 Prinsip-prinsip Pemasaran, Jilid 1. Jakarta: Erlangga.

Kotler, P., \& Keller, K. L. 2006. Marketing Management (11 th ed). New Jessey : Pearson Education, Ing Upper Saddle River.

Kotler, Philip. 2002. Manajemen Pemasaran di Indonesia : Analisis, Perencanaan, Implementasi dan Pengendalian. Salemba Empat. Jakarta.
Peraturan Pemerintah Nomor 19 Tahun 2005 tentang Standar Nasional Pendidikan (Lembaran Negara Republik Indonesia Tahun 2005 Nomor 41, Tambahan Lembaran Negara Republik Indonesia Nomor 4496).

Rakhmat, Jalaludin. 2003. Psikologi Komunikasi. Bandung: Remaja Rosda Karya.

Sugiyono. 2003. Metode penelitian bisnis. Bandung: Pusat Bahasa Depdiknas

Tjiptono, Fandy. 2008. Service Management, Edisi Kedua. Yogyakarta: Andi Ofset.

Tjiptono, Fandy. 2007. Strategi Pemasaran. Edisi Pertama. Yogyakarta: Andi Ofset.

Undang-Undang Nomor 20 Tahun 2003 tentang Sistem Pendidikan Nasional (Lembaran Negara Republik Indonesia Tahun 2003 Nomor 78, Tambahan Lembaran Negara Republik Indonesia Nomor 4301) 